\title{
The Elderly and Life's Channels: The Threads of Life
}

\author{
Elma Jazz Elma-Macrohon, (DScN, MAN, BSN, RN.) \\ Cebu Normal University, Cebu City, Philippines
}

Doi:10.19044/esj.2018.v14n32p253 URL:http://dx.doi.org/10.19044/esj.2018.v14n32p253

\begin{abstract}
This study was undertaken with the aim to validate the assumption in JEM's Theory on Intergenerational Visits to the Elderly, which states that Intergenerational visits promote socialization, that spirals into family solidarity, quality time shared; that affords the elderly parents more meanings, purposes, significance in their lives, the feeling of successfully aging, and make family relationship tighter everytime it happens. It is also to come up with narrative materials from the experiences of the informant-elderly during intergenerational visits, together with children, grandchildren, friends and relatives, before, during, and after the visitation. The method used is narrative inquiry. Interview schedules were used both in Filipino and English. There were recorded interviews and later transcriptions of them, then a story was woven entitled: "The Elderly and Life's Channels: The Threads of Life". There were six parents interviewed equal to six families. The characters in the narrations are representatives from these families. Findings proved that, "intergenerational visits to the elderly", is a key factor to improve the social relationship between children and parents and between and among parents and children. Other findings were on the smooth and rough (conflicts) events in the family, but the latter mended by the faithful observance of intergenerational visits, which serve as the knot that binds family members together, because the former promotes socialization. It is recommended that Intergenerational visits be included in the yearly activities for the elderly people or the senior citizens, by their respective family members, often or even far in-between.
\end{abstract}

Keywords: Intergenerational visits, relationships between and among grandparents, children and grandchildren threads of life, socialization

\section{Introduction}

The JEM Theory on Intergenerational Visits to the Elderly was generated from empirical experiences of the researcher that firmed-up the importance and significance of this type of visits. It enhanced the life's perspectives of the elderly on the imperatives of socialization brought and 
shared with them by their children and respective members of their families of different ages. The theory provides phenomenal and empirical elements. Phenomenal, because of the presence of an event or events (the visits) and empirical, because of the presence of activities that promote socialization, that give meanings and purposes to the elderly, while tying the knots of family relationships tighter.

JEM theory on intergeneration visits to the elderly is used to remind everyone, that the elderly, despite of age, his or her presence brings a glitter of a gem, among and before the family members of different or intergenerational ages, and vice-versa, making the life of the former in full circle.

Intergenerational visits are occasions or events where relationships between children and parents, parents and grandparents, children and their grandchildren, children and their siblings can be strengthened and a socialization process can evolve (Gullen, Mills Jump, 2010). According to Moore (2001), there are sources of intergenerational phenomenon: the family, the marketplace, and the community. The family is the best and strongest among the three sources. This study bears that elderly socialization is guided by sources such as: relatives, persons and mass media. However, the first and the most typical source is the family; and that no other agents of socialization can compare with, the family, because it enjoys a cumulative edge in exposure, communication, and receptivity. The home and family provide character, for the children to imitate, model or identify those attributes of the parents and other elders that are consistent, reinforced and bring happiness to the members. To draw a scenario: the parents are the fulcrum, the children and their children's children as the radii, and intergenerational visits, as the vehicle that ties them together from time to time, regardless of how closely or far-inbetween it is done.

\section{Related Literature}

The literature cited in the following paragraphs, are both foreign and local, that would afford more comprehension and appreciation of the present study.

According to Gullen, Mills and Jump (2010), relationships among siblings' children, and their parents, and grandparents, are termed as intergenerational relationships. That from those relationships will evolve social activities that family solidarity, values are imbibed, and a sense of wellbeing are experienced by the elderly, likewise, the latter develops a feeling of successfully aging.

Emphasis, was placed in the work of Jeste (2010), on the fact that selfdisclosure and high degree of personal involvement are characteristics of intimate relationships among family members. He further underscored that 
elder people who have better central of their lives, have good continuing relationships with family members, and are happier and tend to lead contented lives.

Truly, there are many reasons, why the younger generations should have good and positive interactions and relationships with the elderly members in the family whether living with them or whom they visit from time to time. The atmosphere that they create would be enough as a gesture of thoughtfulness and generosity, especially during visitations, so that the elder ones will not feel lonely and isolated during old age. Since time immemorial it has been said that the family is the smallest unit of society, and that man as a social being starts to experience social activities therein, and expands it as he exposes himself to the larger society. But, that nest, called home, serves as the spring board of his social relationships.

Speaking of the home, as a society, one must not lost sight of the fact that a society is also a home, "writ large" (society enlarged). In this study it serves as the location of the fulcrum, the elderly couple, or singly, left behind, where the members of the family or families serve as the radii, and the intergenerational visits from them, whether frequently done or far-in-between as the vehicle, to bring them back together, into an intergenerational relationships.

In the work of Guzman (2011), it was discussed that the elderly's feelings of loneliness and isolation, should be given attention, because it might be a great contributing ill factor in the health of the former. It was further discussed in the same work, that intergenerational visits have been proven as healthy occasions for the elderly, while social isolation and family separation when prolonged will lead to health risk and harmful to the emotional and mental state of the former.

Spence and Rodunorich (2007), support the thoughts of Eric Erickson, that in social development as a lifespan, the final stage of emotional development is experienced around the age of 60 and older. That the elderly, looks for meanings in his life and how a sense of purpose could be developed. It further, discussed that exposing the lives of younger generations with the older adults in the family can help the latter feel a greater sense of fulfillment. That in sum, exposing the young ones and elderly members in some social activities during intergenerational visits can provide advantages for both. In this manner relationships become richer and significantly far reaching.

There are six different dimensions in the relationships between parents and children, which according to Albertini, Kahli, and Vogel (2007), are: Associational, Affectual, Consensual, Functional, Narrative and Structural. The foregoing relationships could be compounded and experienced during intergenerational visits, inorder to develop, express, and impress social, emotional, and material supports; love; care; and respect for the elderly. 
In the case of the features of the Indian family, Chad (2007), described it as socio-culture-value-laden. The elder ones are regarded of great value to the family members, as shown through the following: families are very special to the members; the manners, like respecting the elders, washing the formers' feet, speaking in dignified manners, taking the elders' advice prior to the making of a decision; and everyone strives to make the members tension-free, happy and being heard. The elderly members are constantly visited and checked with concern.

Changing focus, from the family social activities, to the intercommunity, social activities that are also beneficial to both young and old, Bunn (2012) was of the opinion that, although there will be good possibilities to gather people of different ages at one given time, getting people together, would be the hardest part. He further stated, that time, common schedules, series of interactions, and watchful planning are necessary, for a quality intergenerational relationships to occur. Bosak (2013) described, a Grandparents' Day Celebration as an opportunity, with the attendance of intergenerational groups of a population engaged in social activities. Everyone experienced getting involved among and between groups of intergenerational people, inter-reliant, richly intricate groups, that taught many how to be patient, tolerant, enduring and benefit from all of the interactive activities.

The implication is, whether it is a Grandparents' Day, Community Founders' Day, or a Family Day in an academic institutions, or any place in the community, the personal or individual experiences of empathy amidst the social activities, will always be better felt with a family, than in a larger group. The intimacy, the sense of belongingness, in sum, the benefits derived by the participating genres are more intense and lasting than in the former occasions. Central to the social activities are the older members, who are given importance, reverence, respect, concern and many other values, factored in, for the generations to come.

Another implication is, in one intergenerational social setting in a grandparents' home, future families will be generated, with the social activities experienced which are beneficial for both, as a prototype, making it lasting, poignant, and regenerating, survival of good family social values for the elderly adults and the future generations.

\section{Methodology}

The qualitative method of research was used by the researcher, specifically the narrative inquiry. According to Connely and Clandinin (1990) and Rhodes (2012) the method generates data in the form of stories and typologies of stories. The objects of inquiry are the stories, which are declared as the "oldest" and "most natural" means that people give meaning 
to their experiences. In this research design, they used languages as a means or tool to reveal and share their experiences with others.

There were major informants, among them are the grandchildren two were about to graduate from high school, one $7^{\text {th }}$ grade, one in the $8^{\text {th }}$ grade, and three in their elementary grades. The first of the major informants was the 85 year old grandfather, followed by the 83 year old grandmother. Both were retirees from government employment, and had a conservative business, a family - owned piggery and poultry farms. They also had vegetable farm gardening that ranged from those enumerated from the song "Bahay Kubo".

The children of G-1 were: A, 14 years old, B, 12 years old and C, 10 years old. GA-2's children were: D, 14 years old and E, over 12 years old. GA's-3 children were: F, 8 years old, and G, 6 years old. Therefore, 3 male and 4 female grandchildren came out from their respective families.

The study chose this group of cases because of the set-up and the big number of grandchildren, ranging from 6 to 14 years old, composing of 3 males and 4 females. Besides, they were brought up in two settings local and foreign. Both elements would surely have some influences on the intergenerational visits.

The investigator had exposure on community and family work, what others call the sociology of the families in the communities. She was with a consultant, who was a Psychologist and a Guidance Counselor by past experiences, and a good background of research in Sociology. She opted to use a researcher-made interview schedule on English, translated to Filipino, because Puerto Princesa City, Palawan, Philippines, is a Tagalog/Filipino speaking populated place.

The face to face method of interview was used. Out of the 45 minutes, 15 minutes was used to explain intergenerational visits, and some activities and intricacies that went with it. Some fundamental questions were asked by the main interviewees/informants, for instance: "Kailangan ko bang ibigay ang totoong mga pangalan? ; Kailangan bang detalyeng-detalye ang pagkuwento?; Sino ang mauuna? Pwede ba makisingit kung may dapat itanong?" (Is it necessary that the real names be given? Will the story be told in detailed from? Who will be first? Can I interrupt if there are important questions to be asked?)

The informants were given enough time and their own way of narrating their lives and some important incidents. There was neither prodding made nor interruption done. The research group carried with them some snacks and food for lunch to give them the comfort and the leisure of time without the presence of empty stomachs. 


\section{Ethical Consideration}

With due respect to the informants, the researcher requested for an informed consent from the couple, the three married children (GA-1, GA-2 and GA-3) for themselves and for whichever child or children will be inclusive of the interview. They were given an assurance of confidentiality, as with their children and their respective children. It was made known to them that we will be using pseudonyms of all those who will be with the group of interviewees. There were also am assurance that in no way shall they be forced to answer and if they are not willing to divulge some data, they have the right to remain silent. The reasons of confidentiality and anonymity and even pseudonyms were clearly explained.

\section{Data Analysis}

The data were both in audio and written forms. The recorded data were heard and reviewed. Some of the written data were composed of the informants' recordings, and the researcher's keenness in observation was applied whether there were no inconsistencies with what were uttered and written, and whether observed facial expressions were faithful to what have been narrated. In short the data were gathered through the research technique of Triangulation.

This could be considered a signal study, because in the Philippines, no one has thought of this topic yet to be undertaken as a research. It was only when the investigator was convinced that the world is graying; and that she got interested in the world of the family and the elderly in relation to intergenerational visits.

Through the presence of triangulation, in treating the data of the informants, a story of a family was woven: The Elderly and Life's Channels: The Threads of Life". The story was shared with the informants to establish a sense of trustworthiness.

\section{Results}

Out of the conservative abundance of data, analyzed, classified which underwent a triangulation of their trustworthiness, a story was woven: "The Elderly and Life's Channels: The Threads of Life".

In the year 1967, a lady of 24 years old met a man three summers her senior. It was on a wedding occasion that they met, the young man of 27 , was the groom's best man while the lady was the bride's maid. It was not love at first sight. Several events took place that bridged the two together, until a couple, years later replicated the occasion of that wedding. This time, they were the groom and the bride. That was 1969. It was in the city of Davao, Philippines. 
The coping and adjustment years blest them with three children, two boys and a girl. They were brought up well and closely together, meant to be always there in times of want and plenty, when each shall have a family of their own.

The wedding of Mr. PC and Ms. RM, brought together relatives and their respective families. It was an intergenerational occasion that developed into an activity of socialization until midnight and until the following day. Bringing families together were akin to an intergenerational visit. There were social activities that created and developed family bonds tighter.

Business opportunities and a promising job and career, made the couple transfer to another place, after 15 years of their marriage.

\section{The Setting: A Juxtaposition}

The house of Grandma, was located in an urban area of an academically advanced city... where people's minds and physique are in lively ferment. Her family home existed in the hearts and minds of each member.

There were big schools, as there were many big parks for playgrounds. The playgrounds were mute of elderly people, but no longer now. It has become, like a family, a miniature of a society. The stage of intergenerational actors, but common to the eyes-some elderly in crutches and wheelchairs, rested, walking in turtle pace, some still half walking and jogging, four still with strong brisk-walks, and she was one of them now.

There were two big universities, each competing not for the number of programs offered and student-enrolees, but for its quality and standard of education. The teaching and learning conditions and situations accentuated the lives of the learners, for they made well in their respective fields, in business, in the academes, in politics and in many other fields of endeavors. Some climbed the ladders of success, like the way butterflies often do having its true independence with the coming of maturity; some because of family backgrounds of wealth and power; some due to good connections; others by good fate; others by fervent faith; while others in many ways than one.

The workplaces were few; so employment was scarce. Almost all workplaces were manned by persons of high academic honors and quality educational qualifications. The services were good, to the point of being excellent. The place afforded good opportunities for students and graduates alike, scholarships, trainings both in management and leadership. Some went wayward, but not wanton-but bought and subscribed to other ideologiesopposite, thwarted, but full of idealism for reforms. They said to balance a society and its government, specifically the people who propelled the latter.

Granny 1, earned her education from a conservative school in the city_offering academic-tech-voc education, where she was and that's where 
the new generations are ushered in - the $\mathrm{K}$ to 12 scheme of education, adding more years and the scent of tech-voc-academic type of education, simply placed in another bottle.

However, central to her thoughts is a house and home...the nucleococaie (the family) of a nucluecocos... (The society). Thoughts are running wild in juxtaposition of the past and present; and which are situated to unravel the life of an elderly and her family.

\section{The Alignment: A Protocol}

The years blest the couple with three children. Granpa, the husband, was a businessman, well-educated and cultured, and was the only child of a couple, both in the teaching profession. As what was told, "he cuddles his family well, figuratively and literally speaking. He values it, probably because, he is seen and nurtured with the constellation of a father, mother, grandmother, and other closed and distant relatives. He is 85 years old." The past intergenerational visits of their children brought happy memories.

Grandma, is a supportive wife and mother to her three children, GA1, GA-2 and GA-3. As a retired school teacher, she is gracefully attuned to the lives of her husband and each of her children, and even her grandchildren. They had seven grandchildren. Two of those are about to graduate from high school; two were caught in the $7^{\text {th }}$ and $8^{\text {th }}$ grades of the $\mathrm{K}$ to 12 educational scheme; two are in the grade school and one is in the kindergarten.

GA-1 is a lawyer, doing good, and a private practitioner and teaching part-time in a law school in Manila: Tall, dark and an attractive single looking married man. He's very close to his parents, gentle and concerned for the children. Seldom to be with the family during weekends due to the cases that take him to other places in Manila and the province. In abbreviated words: all signs of a successful lawyer, but still finds time and space for and with the family. He has 3 children and a working wife.

The wife is proud of him because, he is loving, humble, brilliant, honest, thoughtful and concerned for them. He is respected by friends and comrades in the profession. Very often, he visits the parents singly. Only in very few instances, probably, two times with the family. He is 53 years old. As the psychology books state: The eldest child, "is always a successful one, because he is born amidst grown-up people in the family and he interacts with their maturity" (Hall and Lindzy, 1960). GA-1, was both seen and heard in more ways than one, by the couple.

GA-2, 48 years old, a doctor of medicine, is based in California. He is a man with a good sense of humor, friendly, confident, high salaried, away from the Philippines for 10 long years, practical in his own ways, independent, looks "easy-go-lucky", but we have a special nest in his heartalmost a monument, strong and steadfast in all weathers. He is handsome, 
cut after his father, even by nature and characteristics, but he differs from the former's insights and foresights. He graduated from college as a Summa Cum Laude, and was one of the top 10 topnotchers in the Medical Board Exam. Aside from being a Youth Ambassador to the South-East Asian countries, he garnered regional and national medals in contests, academic, oratory, debate, literary writing, and declamations. He visited them twice, singly, and thrice with his family and their other two children's families. But, psychology books state, that "the middle child is a neglected child". The parents defied this statement, as G-A, did.

GA-3, is a daughter with brain, brawn, beauty, and modest to the point of being "very conservative". She is a nurse, married to an accountant and Filipino husband. She has two children in their elementary years of education. She is caring, loving, and a little "spoiled girl", being the youngest. She works in San Francisco for 8 years now. She is 42 years old. Out of love and concern, she calls her parents very often to check on their blood pressures, their activities, and their diet. She wants them to continue in their meeting with other people, as an important part of their "Activities of Daily Living". She visited the couple twice, but alone. She visited them with her family three times, in time with her brothers and their respective families visits. She is quoted to have often said that, "The three intergenerational visits were activities of socialization that bridged her and her brothers and their respective families to walk back and forth in the empty nest of their parents and enlighten their lives everytime“.

\section{The Memories: Sought and Regained}

The couple owned a farm, a run-away from the hub-dub of the city. It was a week caught between the months of May and June, that they normally visit their house in the farm, because of ambivalence of climate - not so hot anymore - the breeze cooler with intermittent rain. The visits were timed on birthdays, wedding anniversaries, baptismal, Christmas, New Year, unscheduled four visits and to host friends and relatives from other places. Their childhood experiences spawned over trips in the country sides, beaches, and island hoppings.

All the visits were captured in cameras, recorded in pictures-happy, happy memories, when they were still single until they were married and with children. Amidst all these years - they never heard the coined words of "intergenerational visits". So they came in and out of their lives to occupy dominantly in their old minds' thoughts.

Grandma, remembered what her father said, who died at the age of 95. "The difference between the young and old in terms of remembering poignant memories, is that, the young use their feet to retrace paths, they go up the hills and mountainsides to look back and over the years, while the old 
ones trace the past by unraveling the threads of both happy and sad memories on the hilltops and mountaintops of their minds". Perhaps, made abundant, richer and broader in spectrum, seated in a rocking chair, in a house, built overlooking other hills, the Tres Marias islets, the Hulugan and Oyster Bays, and the beaches of white sand.

It was GA-3's wedding, when most of their close and distant relatives, friends and families were invited. There was a community of people, intergenerationally speaking the Lolos, the Lolas, the Uncles and Aunties, the immediate families of two kasambahays, and our neighbors' families. The scenario central to the glee and chaos of movements, sounds, and music was the newlywed couple, looking blest and with seemingly unconsumable happiness. Present were four pregnant nieces, two newly-wed couples, there were nephews and their sweethearts, playful children running here and there. The dance area was an intergenerational floor, because while there were children, adolescent, younger adults, there were also middle-aged adults who danced in-step with the young ones. It was an event where they revived ages and happy to have survived the years. When you reach 65 you have received a "bonus" in life. Besides, beyond that life becomes both "a given and a gift". This was a grand intergenerational visit for the whole week. Her husband and she embraced these poignant memories with tenderness.

The three intergenerational visits of their children and the members of their respective families were characterized with satisfaction, joy, happiness, sharing of time, material and emotional supports - in sum all full of rewarding experiences of old people now 85 and 83 years old. The skewed and contrapuntal experiences were negligible and easily eclipsed with the happy, rewarding and positive ones to all. All the activities during the intergenerational visits promoted events of socialization and produced happiness.

The intergenerational visits that followed were socializations on occasions like: baptismal, birthdays, fiestas, wedding anniversaries, get together. The activities shared planned and unplanned were: swimming, cycling, climbing the hills, beach combing and beach walking, card making, dancing, cooking, watching shows in theaters and TV sets, storytelling of our childhood memories, trips to neighboring towns to visit relatives, the summer vacations in our farm, island hopping, trail-making/walking, prayer time, bahay-bahayan, camping, bonfire in the farm and a lot more. Every time these happen, they know that the ties of family members are tightened through the socialization created by activities during intergenerational visits.

It was during the fourth intergenerational visit that came so soon, barely a span of a year, actually December of 2013, when Grandpa was diagnosed of severe pneumonia, and of severe arthritis. Upon hearing the news, the children and grandchildren flew home. Upon arrival the house was 
silent of Christmas decor and mute of Christmas songs. Grandpa, was in bed and Grandma was in a wheelchair.

Carlos, GA-1's eldest son, said, "Hindi ganito noon, ang saya-saya nating lahat" (It was not like this before, we were so happy together).Andrea, GA-2's daughter responded, "Yes, times have changed, but since we are all around, they will soon get well".

Ga-a and Ga-b, were with their laptops. Ga-c was watching the two younger cousins, Ga-d and Ga-e seated near the bedside of their grandpa, silent and sleepy. Ga-a and Ga-b were sons of GA-1 and GA-2 respectively. Ga-c was the third child of GA-1. The two sons and GA-3 were often seen talking in whispers. Their wives took on the household chores, the husband of GA-3, was the errand to drugstores.

Grandpa refused to be confined to a hospital, so with Grandma. Grandpa was heard saying, "Sayang lang ang pagbibisita ng mga anak at apo natin kung nasa ospital tayo". (The visiting time of our children will only go to waste if we are confined in a hospital.)

Supper was served early. Prayers, were shorter than before, because, mostly was on personal intentions exclusively for their grandparents. Three days after their homecoming, relatives on both sides started to arrive when they heard the news on how serious was the condition of Grandpa. He was visited three times a day by their family doctor. The children took turns in watching them. Four relatives arrived with their children. The atmosphere started to improve. They were singing in tender voices, the small children, chuckling hesitantly careful not to disturb the sick. This time the house wore bright colored decorations. Christmas songs were played.

Surprisingly, on the fourth day, Grandpa, sat up and started walking. At breakfast time, the doctor declared that the critical period was over. The older members clapped their hands and scratch smoothly Grandpa's back. The small ones were jumping with glee.

Grandpa looked ten years younger, wore a smile almost a laughter. Grandma was full of smiles, with hands clasp, which was for Thanksgiving. The trial is over. It is another gift of life. That night was the birth of Jesus. Bells at a distance church started to chime. Carolers, started to go around from one house to another. The family circle and relatives, with their families started some activities----a memorable socialization promoted by an unplanned and unscheduled intergenerational visit, due to a critical situation of the grandfather. Every time there was an occasion, they all knew that the knot tied between and among family members tightens, through the socialization which is promoted by intergenerational visits.

Inspired by the beauty of the story, this poem is wholeheartedly written by the researcher, dedicated to the immediate family members of the relatives of both sides. 


\section{The Homecoming}

When, we shall grow old and

Become gray-haired shadows to forget,

Only our happy memories and

Only the painful remembrances

Shall be here with unexiled

vows and never with regrets.

Remember dear ones our promises,

That when we shall have gone,

The iron gate will still open with a creak,

To your homecoming with a tight embrace

to our home-a treasured place.

Then ...there...up the overlooking hill,

Of sun ...sky... and sometimes rain,

There, shall we be in canticles of vines and wild roses,

Waiting... for your hugs and warm embraces..

$$
\text { By: J.E.M. }
$$

\section{Conclusion}

On the basis of the activities which were sometimes planned and unplanned, but always shared between, among and with family members during intergenerational visits - the conclusion goes, "intergenerational visits promote socialization has been validated". The activities that are aligned, one after the other, sometimes separately together were socializations promoted during the intergenerational visits, developing and firming-up the bonds that make family relationships tighter from one generation to another.

\section{Reference:}

1. Albertini, M., Kohli, M. Vogel, C. (2007). Intergenerational transfer of time and money in European families: common patterns-different regimes. Europe. Journal of European Social Policy.

2. Bunn, J. (2012) (N.D.). Retrieved from the Christian Network Website www.cbn.com/family

3. Bosak, S. (2013). Grandparents' day planning and activities guide \& legacy project Chair SV Bosak. Retrieved from Legacy Project Website www.legacyproject.org

4. Chad, K. (2007). Intergenerational relationships. India, Delhi University. 
5. Connely, M. \& Claudini, S. (1990). Stories of experiences and narrative inquiry U.S. American Education Research Association.

6. Gullen, M. Mills, T. J Jump, J. (2002). Family relationships in an aging society. Florida. University of Florida. IFAS Extension Journal. Retrieved from http:/edis,ifas.utl.ed/ty 625

7. Guzman, R. (2004). Born to be mild. Times, U.S., National Institute of Aging.

8. Jeste, D. (2010) Successful cognitive and emotional aging, U.S.A., World Psychiatery

9. Meriam, S. (2009). Qualitative research: a guide to design and implementation $\left(2^{\text {nd }}\right.$ Ed.), San Francisco CA: Jossey - Bass.

10. Meriam-Webster (2014) Lasting: Meriam-Webster dictionary. Retrieved from www.meriamwebster.com

11. Moore, S., Wilkie, W. \& Lutz J. (2001). Passing the torch: intergenerational influence as a source of brand equity. Working research paper. Graduate School of Business, University of Notre Dame.

12. Padua, R. (2012). Teaching theory development. Retrieved from www.phenomanologyonline.com/inquiry/orientation-inphenomenology/hermeneutical-phenomenology

13. Rhodes, P. (2012). Narrative inquiry. Retrieved from www.slideshare.net

14. Spence, L. \& Radunorich, L. (2012). Developing intergenerational relationships, family, youth, and community. Florida, Science Department Community Extension Services, University of Florida, FCS 2282. 